\title{
Introducing a Conceptual Framework for the Strategic Classification of State-Sponsored Social Entrepreneurship: A Conceptual Study
}

Amir Forouharfar, Seyed Aligholi Rowshan, Habibollah Salarzehi

\author{
Department of Public Administration, \\ University of Sistan and Baluchestan, \\ Zahedan, Iran.
}

E-mail:

amir.forouharfar@gmail.com,asr@hamoon.usb.ac.ir,salarzehi@mgmgt.usb.ac.irf

\author{
Received : 14 January 2018 \\ Accepted : 2 May 2019 \\ Online First: 26 June 2019
}

\section{ABSTRACT}

Scholars of social entrepreneurship have yet to propose a classification of strategies employed by states to promote SE. The paper's aim is to introduce a conceptual framework for state-sponsored SEs to fill this gap. Such a necessity rises out of the strategic study of the states' role in the promotion of SE intra- and extraterritorially. The paper not only propose strategic mix for the formulation of state-sponsored SE, but also presented a conceptual framework based on the tendency of states toward four orientations of internationalism, internalism, governmentalism and volunteerism for pursuing SE in a macro-scale. Finally, four comprehensive SE strategies namely Opened Door Strategy, Closed Door Strategy, Global Citizen Strategy and Country Citizen Strategy based on the four orientations were proposed. The theoretical implication of the framework is in its contribution to the classification of governmentally promoted SE for a more clarified study and teaching of SEs in the academic context. Its practical implication is in its application as a guideline for sound formulation of SE strategies by public organisations in the public and third sector contexts.

Keywords: social entrepreneurship (SE), strategy, strategic classification, state-sponsored social 


\section{INTRODUCTION}

Entrepreneurship could potentially have strategic impacts, and must not be neglected by economically developed states. The Presidential Summit of April 26, and 27, 2010, held in Washington, DC, at the Ronald Reagan Building with the strategic focus on entrepreneurship is one of the examples of state consciousness towards entrepreneurship. Moreover, the existence of a governmental body or ministry for pursuing social affairs such as social security or fulfilling social needs effectively in any governments, logically justifies the necessity of having locally or nationally customised social entrepreneurship (SE) strategies by the governments. Setting aside the controversy that how government which inevitably must be run by bureaucracy could be entrepreneurial, governments all around the world are getting familiar with the power of entrepreneurship for running their states. When these governments release statistics on the number of job opportunities provided for their nations or number of social problems tackled by innovative measures, they are inevitably talking about the fruits of the entrepreneurship tree. SE, which could be defined as 'a socially mission-oriented innovation which seeks beneficial transformative social change by creativity and recognition of social opportunities in any sectors' (Forouharfar, Rowshan \& Salarzehi, 2018) has a capacity to be looked as a strategic tool in the toolbox of governments for the promotion of public welfare. Social entrepreneurs as the communal change makers (Adetu, 2014; Drayton, 2002; Dees, Emerson \& Economy, 2002) have the capability of contributing states to promote socially benefiting initiatives and enterprises under a well-defined state strategy. However, public SE strategies still do not have any overall strategic framework so as to be classified and understood within. To compensate this research gap, the following research question is posed:

What literature-supported variables should be included in a conceptual framework for the taxonomy of large-scale SE strategies? 


\section{LITERATURE REVIEW}

Not only strategic entrepreneurship is still 'an emerging concept' (Kuratko \& Audretsch, 2017) but also social entrepreneurship is a phenomenon 'in the stage of conceptualisation' (Sekliuckiene \& Kisielius, 2015). This situation adds to the perplexity and ambiguity of what strategic SE concept means. Yet, numerous attempts were made from 'conceptual understanding' of SE itself (Choi \& Majumdar, 2014, p.363) to the conceptualisation of social entrepreneurs' behavioural characteristics (Weerawardena \& Mort, 2006). Mort, Weerawardena and Carnegie (2003) 'conceptualises social entrepreneurship as a multidimensional construct involving the expression of entrepreneurially virtuous behaviour to achieve the social mission, a coherent unity of purpose and action in the face of moral complexity, the ability to recognise social value-creating opportunities and key decisionmaking characteristics of innovativeness, proactiveness and risk-taking.' Few however, have ever set forth to conceptualise strategic SE, thus a research gap that calls for strenuous efforts to be filled. Chandra, Jiang and Wang (2016) believe despite the burgeoning research on social entrepreneurship (SE), SE strategies remain poorly understood.

According to Dharani (2014) 'conceptualisation is the formation of an abstract principle in the mind of a researcher in order to answer the question under observation, basing it upon the available evidence.' By reviewing SE strategic literature we frequently face concepts such as social value making (Nicholls, 2006), social innovation (Mulgan, 2006), strategic social impact (Rawhouser, Cummings \& Newbert, 2019); social mission (Forouharfar, 2018); volunteerism (Gandhi \& Raina, 2018); impact scaling (Dees, 2008), etc. Therefore, any literature-based conceptualisation of strategic SE should be constructed upon the extraction of the most unanimous and frequent concepts in this realm. Although, numerous researchers have tried to conceptualise various strategic manifestations of entrepreneurship, e.g. from 'developing a conceptual framework of strategic entrepreneurship' itself (Luke, Kearins \& Verreynne, 2011) to 'conceptualising corporate entrepreneurship strategy' (Ireland, Covin \& Kuratko, 2009), the realm of strategic SE is under-conceptualised. Thus, one of the attempts in the conceptualisation of strategic SE was Customised SE Strategy, which intends the sustainable development of any country via customised and tailored SE practices, based on the priorities of each country's social problems (Rowshan \& Forouharfar, 2014). 
On the other hand, in strategic approach to SE, two levels are identifiable: a macro-level and a micro-level. According to Nicholls (2009), these arenas of SE embrace a vast spectrum from a macro interference to compensate the gaps in 'institutional voids' (e.g. BRAC and Grameen Bank) or micro customised technical solutions to local communities (e.g. Kickstart's East Africa low-priced marketing of water pumps). Concerning the macro-level, SE has the capability of a social movement or a strong force behind 'societal cognitive frames' which are in 'sub-optimal' (or below satisfactory) circumstances and makes a satisfactory change by generating innovation on 'macro-political level' (Zald \& Davis, 2005; Zald, 2000).

According to Forouharfar (2018), SE in the public sector is on a macro level. Governments have regulatory and policy-making roles and they could have a facilitating role for SE, as well. In other words, they pave the way for the not-for-profits, NGOs, social enterprises, benevolent entrepreneurs, etc. to play in the playground field which is beaten and prepared by the governments. Therefore, two types of strategies could be seen in SE. One type is the macro-strategies, which are applied by the governments and the other are the micro-strategies used by the operational social entrepreneurs.

Replication strategies and Scaling strategies are two major classes of SE strategies (Tracey \& Jarvis, 2007; Bloom \& Smith, 2010). Replication is 'the process by which a cell or DNA makes an exact copy of itself' (Longman Dictionary, 2007). In the strategic SE, it is letting the other SE to exactly copy the successful approach and techniques of a recognised example of SE. Scaling in strategic SE focuses on the amplification of the impact of $\mathrm{SE}$, i.e. increasing the SE impact to be as equal as the social problem in degree and magnitude (Dees, 2008), and to be certain that a great number of people will receive the social services (Ahlert et al., 2008). Reviewing the literature on SE strategies (e.g. Manton, 2005; Volkmann, Tokarski \& Ernst, 2012; Dees, Anderson \& Wei-Skillern, 2004; Grieco, 2015; London $\&$ Hart, 2011) the strategies would fall within one of the following:

(1) Dissemination Strategy

(2) Social Affiliation Strategies

(3) Social Joint Venture Strategy

(4)Social Licensing Strategy

(5) Social Franchise Strategy 
(6) Social Price-Differentiation Strategy

(7) Social Cross-Subsidisation Strategy

(8) Social Microfinance Strategy

(9) Base-of-the-Pyramid Strategy

For the strategic implementation of the abovementioned SE strategies on the large-scale perspective (i.e. countrywide impact), governments have a key role. Shockley and Frank (2011) believe: ' ...little or no social change resulting from social entrepreneurship could have become 'large-scale' without the enabling institutions, resources, and policies of government, even ones with reputations for inefficiency or corruption.' While discussing 'government as problem solver', Dees (2007) truly accentuates that, 'it has become clear that large-scale, top-down government programmes have serious drawbacks.' Yet, governments should set national SE strategies and avoid propensity of socialist governments that is too much intervention in SE affairs. Volunteerism is a recurring occurrence in strategic SE since 'social enterprises often rely upon volunteers to serve key functions, such as board members, to help with fundraising or to provide professional services, or as staff to deliver their services on the ground' (Austin, Stevenson \& WeiSkillern, 2012). Moreover, a resource-based view in strategic management; hence strategic SE, looks inwards or internally, but too much insistence on strategic resource-based view would potentially lead to halo effect in strategic SE. Zander and Zander (2005) asserts, "Extensions of the resourcebased view suggest that the inward-looking perspective has produced an overly narrow understanding of how firms may generate rents and secure long-term growth." Concerning SE, Cheah, Amran and Yahya (2019) believe internal oriented resources (i.e., entrepreneurial orientation, social salience and business planning) under the moderating effect of 'socio-economic context' could influence the social performance and financial achievement of social enterprises. In contrary, instead of looking inwardly, some countries benefit from international SE organisations (Forouharfar, 2018) and 'international for-profit social entrepreneurs' (Marshall, 2011). Usually governments has close cooperation with the UN, UNHCR, UNESCO, UNDP, GEM, ECOSOC, World Bank, World Economic Forum, and world renown SE organisations such as Ashoka, Schwab, Skoll, for the promotion of SE intra- or inter-states, i.e. locally or globally. These international SE organisations usually have a strategic usage of bricolage in order to mobilise their resources in the target countries (Desa, 2012). 


\section{RESEARCH DESIGN AND METHODOLOGY}

This paper is a non-empirical study of large-scale SE strategies in order to introduce a conceptual framework for the classification and study of state-sponsored SE strategies. As a conceptual paper the research intends to go 'beyond summarising recent research, [...] provide an integration of literatures, offer an integrated framework, provide value added, and highlight directions for future inquiry. [...] not expected to offer empirical data'(Gilson \& Goldberg, 2015). Thus, by reviewing the highly cited Google Scholar-indexed literature on SE strategies, the study seeks integration of SE large-scale strategy literature in a conceptual framework. Hence, the integration to the authors means unification and consolidation of the largescale SE in a logically literature-supported framework to provide conceptual value addition for the future classification and accordingly discussion of state-sponsored SE. Moreover, according to Whetten (1989) a conceptual paper should be judged and formed based on seven criteria: (a) what's new? (b) so what? (c) why so? (d) well done? (e) done well? (f) why now? (g) who cares? Hence, (a) the newness lies in the taxonomy of large-scale SE strategies; (b) it introduces a framework for the strategic classification of macro-scale SE; (c) the underlying logic is filling the current research gap in strategic SE studies; (d) the completeness of the conceptualised framework rests in its reliance on relevant highly-cited literature; (e) the paper is shaped gradually based on a methodological flowchart presented in Figure 1; (f) the timeliness and need to such a study lies in coordinating SE researches with facts on the ground, since 'a literature review of research on social entrepreneurship reveals that academics and practitioners seem to be operating in separate spheres' (Hand, 2016) and finally (g) the paper potentially not only contributes to the state policy makers in the matters relevant to SE, but also makes a linkage between SE and public administration, that is the type of SE strategies which could be applied in the realm of public administration. 


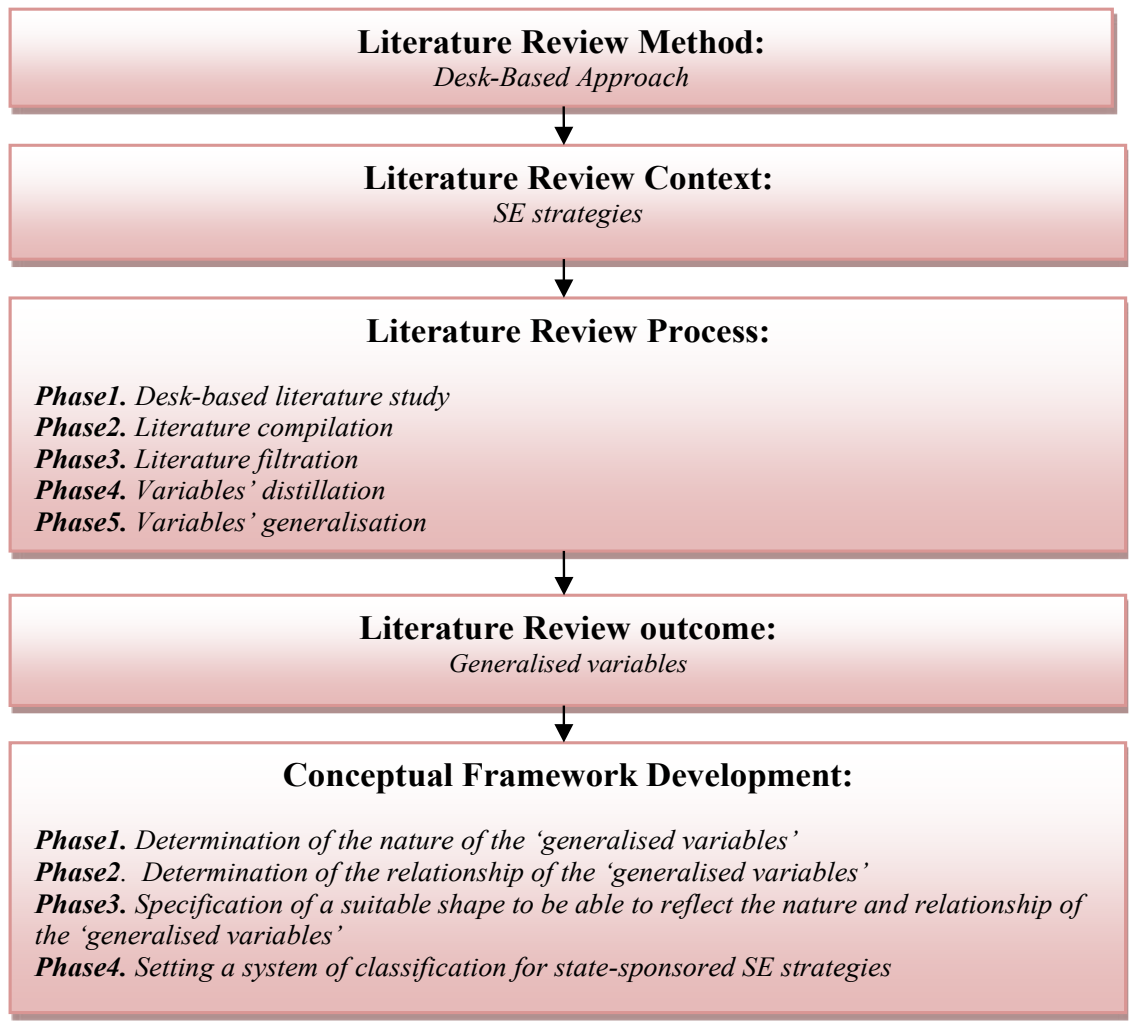

Figure 1: Methodological Flowchart of the Research

According to the research methodological flowchart; presented above in Figure 1, and based on the research question, which calls for a comprehensive study of the literature, the methodological approach is deskbased. Therefore, the research data are secondary non-empirical data. The research question determined the literature context; hence, SE strategies. In the next stage, the literature on SE strategies was reviewed in five phases:

\section{Phase 1: Desk-Based Literature Study}

The source for the selection of the relevant literature was Google Scholar because of its ease of access, comprehensiveness, and searching SE literature based on the literature context in this study. 


\section{Phase 2: Literature Compilation}

Compilation of nearly all SE strategies' variables.

\section{Phase 3: Literature Filtration}

Filtration of the literature variables based on their relevance to strategic SE.

\section{Phase 4: Variables' Distillation}

Extracting the essential variable, which would potentially contribute the promotion of state-sponsored SE.

\section{Phase 5: Variables' Generalisation}

Generalisation of the extracted state-sponsoring SE variables presented in the following:

(1) governmentalism;

(2) volunteerism;

(3) internationalism; and

(4) internalism. 
Introducing A Conceptual Framework for the Strategic Classification of State-Sponsored Social

Table 1: Literature Review Method, Context, Process and Results

\begin{tabular}{|c|c|c|c|c|}
\hline \multicolumn{5}{|c|}{ Literature Review } \\
\hline \multirow[t]{2}{*}{ Method } & \multirow[t]{2}{*}{ Context } & \multicolumn{2}{|c|}{ Process } & \multirow{2}{*}{$\begin{array}{c}\text { Final } \\
\text { Results }\end{array}$} \\
\hline & & Phase & Purpose & \\
\hline \multirow[t]{5}{*}{$\begin{array}{l}\text { Desk-Based } \\
\text { Approach }\end{array}$} & \multirow[t]{5}{*}{$\begin{array}{l}\text { SE } \\
\text { strategies }\end{array}$} & $\begin{array}{l}\text { Phase 1: } \\
\text { Desk-based } \\
\text { literature study }\end{array}$ & $\begin{array}{l}\text { Acquisition } \\
\text { of secondary data }\end{array}$ & \multirow{5}{*}{$\begin{array}{l}\text { Four } \\
\text { generalised } \\
\text { large-scale } \\
\text { variables for } \\
\text { strategic SE }\end{array}$} \\
\hline & & $\begin{array}{l}\text { Phase 2: } \\
\text { Literature } \\
\text { compilation }\end{array}$ & $\begin{array}{l}\text { Compilation of SE } \\
\text { literature }\end{array}$ & \\
\hline & & $\begin{array}{l}\text { Phase 3: } \\
\text { Literature } \\
\text { liltration }\end{array}$ & $\begin{array}{l}\text { Filtration of the } \\
\text { literature variables } \\
\text { based on their } \\
\text { relevance to } \\
\text { strategic SE }\end{array}$ & \\
\hline & & $\begin{array}{l}\text { Phase 4: } \\
\text { Variables' } \\
\text { distillation }\end{array}$ & $\begin{array}{l}\text { Extraction of the } \\
\text { strategic and state- } \\
\text { sponsoring SE } \\
\text { variables }\end{array}$ & \\
\hline & & $\begin{array}{l}\text { Phase 5: } \\
\text { Variables' } \\
\text { generalisation }\end{array}$ & $\begin{array}{l}\text { Generalisation of } \\
\text { the extracted state- } \\
\text { sponsoring SE } \\
\text { variables }\end{array}$ & \\
\hline
\end{tabular}

(Source: Authors'own work)

Later, the conceptual framework was developed based on the nature of the 'generalised variables', which stand at the opposite extremes. Table 2 has summarised the complete literature review process to reach the research 'generalised variables'. 
Table 2: Research Literature Review Process

\begin{tabular}{|c|c|c|c|}
\hline \multicolumn{4}{|c|}{ Literature Review Process } \\
\hline Phases & Explanations & $\begin{array}{l}\text { Derived } \\
\text { Concepts }\end{array}$ & $\begin{array}{l}\text { Reviewed } \\
\text { Literature }\end{array}$ \\
\hline $\begin{array}{l}\text { Phase 1: } \\
\text { Desk-based } \\
\text { literature study }\end{array}$ & $\begin{array}{l}\text { Led to the second } \\
\text { phase's concepts }\end{array}$ & $\begin{array}{l}\text { 1. Social value } \\
\text { 2. Social } \\
\text { innovation } \\
\text { 3. Social } \\
\text { opportunity seeking } \\
\text { 4. Social change } \\
\text { 5. Social welfare } \\
\text { 6. Social results } \\
\text { 7. Strategic } \\
\text { social impacts } \\
\text { 8. Social mission } \\
\text { 9. Social } \\
\text { volunteerism } \\
\text { 10.Governmental } \\
\text { social intervention } \\
\text { 11. International } \\
\text { social cooperation } \\
\text { 12. Internally- } \\
\text { oriented social } \\
\text { services }\end{array}$ & $\begin{array}{l}\text { The following } \\
\text { Google Scholar } \\
\text { highly-cited SE } \\
\text { literature. }\end{array}$ \\
\hline $\begin{array}{l}\text { Phase 2: } \\
\text { Literature } \\
\text { compilation }\end{array}$ & $\begin{array}{l}\text { SE literature } \\
\text { compilation }\end{array}$ & Social value & $\begin{array}{l}\text { Nicholls, 2006; } \\
\text { Dees, 1998b; } \\
\text { Hibbert, Hogg \& } \\
\text { Quinn, 2002; } \\
\text { Austin, Stevenson } \\
\text { \& Wei-Skiller, } \\
\text { 2012; Alvord et al., } \\
\text { 2004; Mort, } \\
\text { Weerawardena \& } \\
\text { Carnegie, 2002; } \\
\text { Sarasvathy \& } \\
\text { Wicks, 2003; } \\
\text { Peredo \& McLean, } \\
\text { 2006; Anderson } \\
\text { \& Dees, 2002; } \\
\text { Townsend \& Hart, } \\
\text { 2008. }\end{array}$ \\
\hline
\end{tabular}




\begin{tabular}{|l|l|l|}
\hline & Social innovation & van der Have \\
& \& Rubalcaba, \\
& 2016; Mulgan, \\
& 2006; Nicholls \& \\
& Murdock, 2011; \\
& Phillips et al., \\
& $2015 ;$ Dawson \\
& \& Daniel, 2010; \\
& Goldsmith, \\
& 2010; Franz, \\
& Hochgerner \& \\
& Howaldt, 2012; \\
& Maclean, Harvey \\
& \& Gordon, \\
& 2013; Westley \\
& \& Antadze, \\
& $2010 ;$ Nicholls \& \\
& Murdock, 2012; \\
& Tapsell \& Woods, \\
& $2010 ;$ Tapsell, \& \\
& Woods, 2008; \\
& Lisetchi \& Brancu, \\
& 2014; Chalmers, \\
& 2013. \\
\hline
\end{tabular}




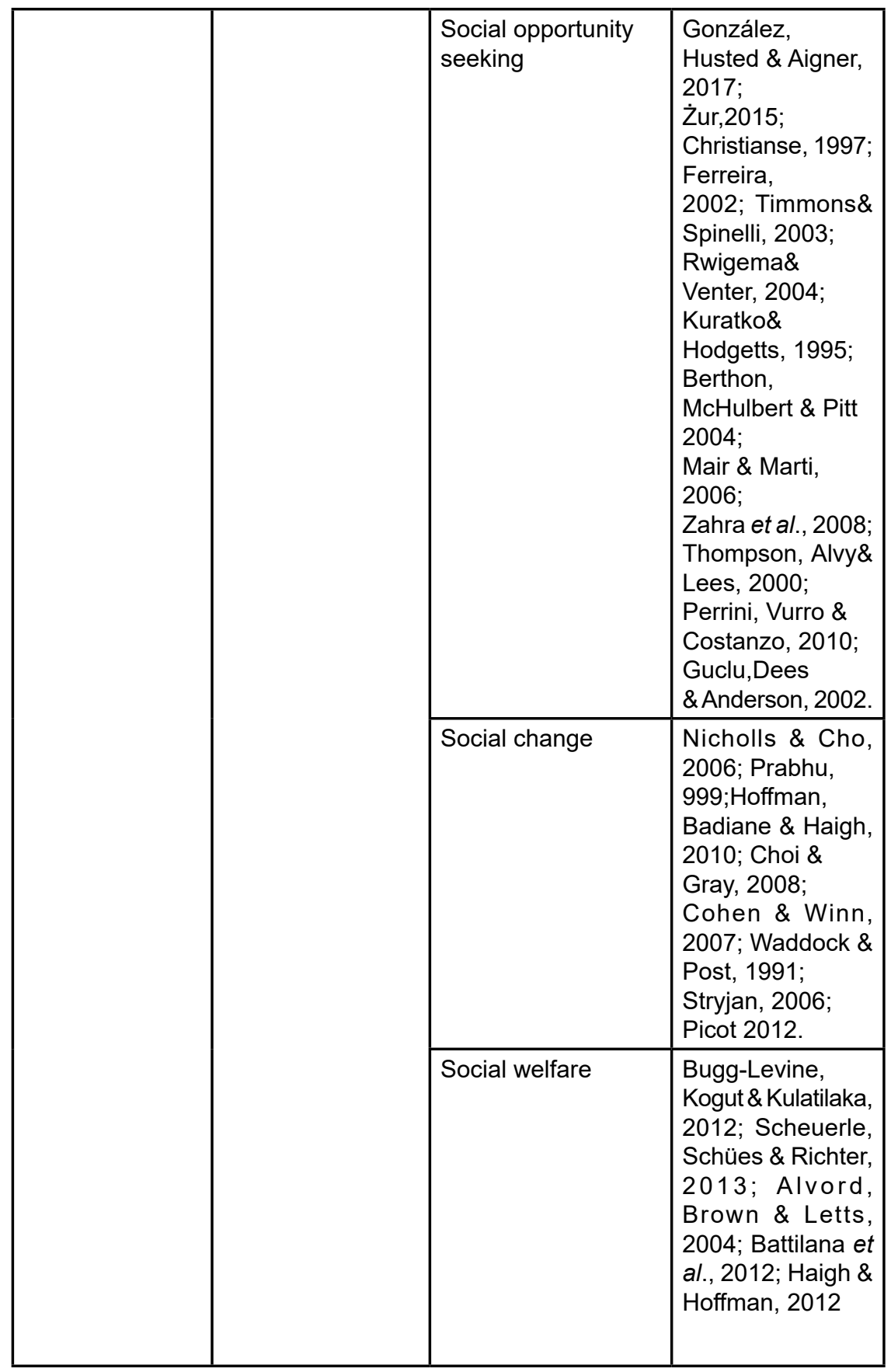




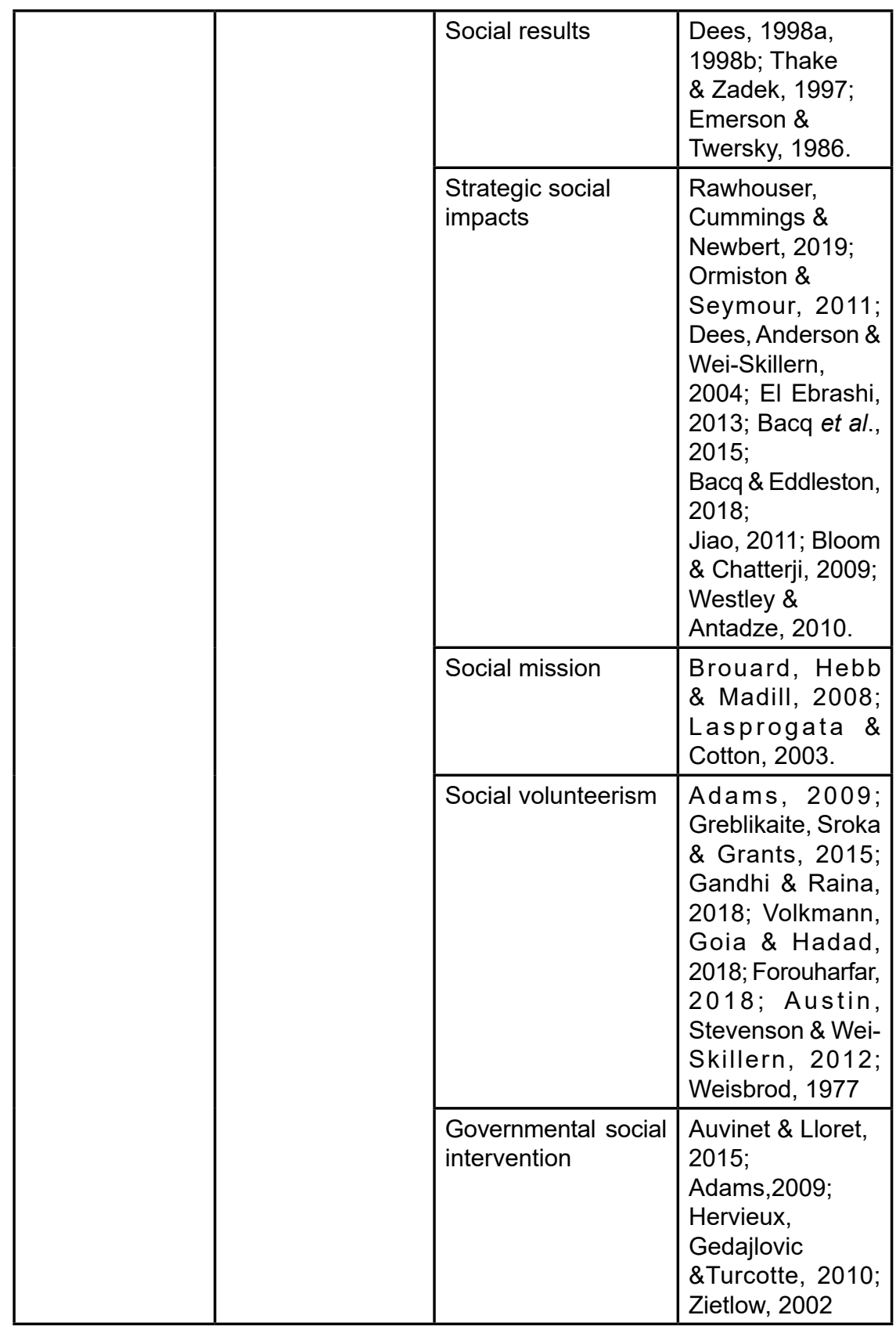




\begin{tabular}{|c|c|c|c|}
\hline & & $\begin{array}{l}\text { International social } \\
\text { cooperation }\end{array}$ & $\begin{array}{l}\text { Galera \& Borzaga, } \\
\text { 2009; } \\
\text { Nicholls, 2008; } \\
\text { Munoz, 2010; } \\
\text { Kerlin, 2006; } \\
\text { Kerlin,2010; } \\
\text { Forouharfar,2018; } \\
\text { Huda et al., 2019; } \\
\text { Zahra, Newey \& } \\
\text { Li, 2014; } \\
\text { Davis, 2016. }\end{array}$ \\
\hline & & $\begin{array}{l}\text { Internally-oriented } \\
\text { social services }\end{array}$ & $\begin{array}{l}\text { Cheah, Amran } \\
\text { \&Yahya, 2019; } \\
\text { Forouharfar, } \\
\text { 2018; Gras \& } \\
\text { Lumpkin, 2012. }\end{array}$ \\
\hline $\begin{array}{l}\text { Phase 3: } \\
\text { Literature } \\
\text { filtration }\end{array}$ & $\begin{array}{l}\text { SE Literature } \\
\text { filtration } \\
\text { based } \\
\text { on relevance } \\
\text { to strategic SE }\end{array}$ & $\begin{array}{l}\text { 1. Social } \\
\text { volunteerism } \\
\text { 2. Governmental } \\
\text { social intervention } \\
\text { 3. International social } \\
\text { cooperation } \\
\text { 4. Internally-oriented } \\
\text { social services } \\
\text { 5. Social mission } \\
\text { 6. Strategic social } \\
\text { impact }\end{array}$ & \\
\hline $\begin{array}{l}\text { Phase 4: } \\
\text { Variables' } \\
\text { distillation }\end{array}$ & $\begin{array}{l}\text { SE Literature } \\
\text { distillation based } \\
\text { on state- } \\
\text { sponsoring } \\
\text { variables }\end{array}$ & $\begin{array}{l}\text { 1. Social } \\
\text { volunteerism } \\
\text { 2. Governmental } \\
\text { social intervention } \\
\text { 3.International } \\
\text { social } \\
\text { cooperation }\end{array}$ & \\
\hline & & $\begin{array}{l}\text { 4. Internally-oriented } \\
\text { social services }\end{array}$ & \\
\hline
\end{tabular}




\begin{tabular}{l|l|l|l|}
\hline $\begin{array}{l}\text { Phase 5: } \\
\text { Variables' } \\
\text { generalisation }\end{array}$ & $\begin{array}{l}\text { SE Variables' } \\
\text { generalisation } \\
\text { based on } \\
\text { their strategic } \\
\text { orientations }\end{array}$ & $\begin{array}{l}\text { 1. Volunteerism } \\
\text { 2. Governmentalism } \\
\text { 3. Internationalism } \\
\text { 4. Internalism }\end{array}$ & \\
\hline
\end{tabular}
(Source: Authors'own work)

Since governmentalism/volunteerism and internationalism/internalism ori entations have contrary natures, then they stand at either extreme that is logically they must have inverse or negative correlative relationship. For example, by the increase in one of the extremes there should be a decrease in the other. Therefore, the generalised variables must have logically inverse correlation, which could be presented on a coordinate axis system (Table 3 ).

Table 3: Research Conceptual Framework Development Components

\begin{tabular}{|l|l|l|l|}
\hline \multicolumn{4}{|c|}{ Conceptual Framework Development } \\
\hline Variables & \multicolumn{1}{|c|}{ Nature } & \multicolumn{1}{|c|}{ Relationship } & $\begin{array}{l}\text { Form } \\
\text { (Visualisation) }\end{array}$ \\
\cline { 1 - 1 } 1. Governmentalism & Contrary & $\begin{array}{l}\text { Logically inverse } \\
\text { correlation }\end{array}$ & $\begin{array}{l}\text { Coordinate Axis } \\
\text { System }\end{array}$ \\
\cline { 1 - 2 } 2. Volunteerism & Contrary & $\begin{array}{l}\text { Logically inverse } \\
\text { correlation }\end{array}$ & \\
\cline { 1 - 2 } 3. Internationalism & & 4. Internalism \\
(Source: Authors'own work)
\end{tabular}

In the final stage, based on the constructed conceptual framework and its variables, four classes of SE strategies, which could be applied by governments were proposed.

\section{RESULTS AND DISCUSSION}

Looking strategically at SE, two arenas could be assumed before it: a macro arena and a micro one (Figure 2). The macro-level orientation is outward since governments usually set some strategies for the promotion of SE not to be implemented by themselves but via SE organisations (SEO); in contrary, the micro-level orientation is inward, since SEOs set strategies for their own application and enforcement based on their predefined social 
mission(s) and vision(s). Moreover, the states pursuing SE deal with the macro-level of SE with its necessities.

Macro-level strategic SE view by governments

(Outward orientation)

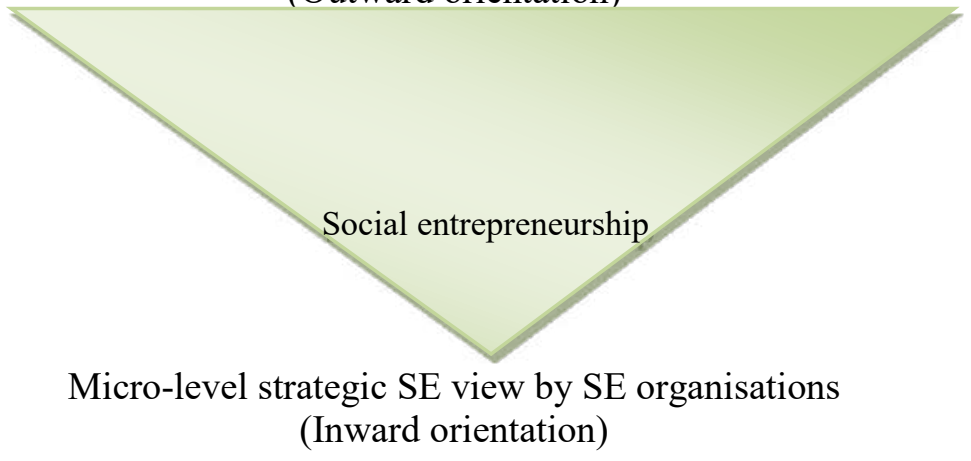

Figure 2: Strategic Views toward SE

(Source: Authors'own work)

On the other hand, each government could benefit from a strategic mix for formulating its state-sponsored SE. The SE strategic mix could be consisting of three items: (1) governmental strategic positioning toward SE; (2) possible SE strategies and (3) intended results (Table 4). By different mixing of these three items, the governments can customise their appropriate kind of SE strategy setting. For example in case of scaling strategy, by the strategic mix, a government can set an aggressive scaling strategy, a defensive scaling strategy, a proactive scaling strategy, a cooperative scaling strategy, a competitive scaling strategy, and a co-optative scaling strategy based on the conditions of the target community and its external and internal environments (strengths, weaknesses, opportunities and threats). Choosing different items from the strategic mix metaphorically acts as a dimmer. The governments can increase or decrease the social impact of the set strategy accordingly. 
Table 4: Proposed Strategic Mix for State-Sponsored SE

\begin{tabular}{|l|l|l|}
\hline $\begin{array}{l}\text { Governmental strategic } \\
\text { positioning toward SE }\end{array}$ & SE Strategies & Intended Results \\
\hline Aggressive & $\begin{array}{l}\text { Scaling Strategy } \\
\text { Replication Strategy } \\
\text { Defensive }\end{array}$ & $\begin{array}{l}\text { Either } \\
\text { Scaling-up } \\
\text { or } \\
\text { Replication }\end{array}$ \\
& $\begin{array}{l}\text { Social Affiliation } \\
\text { Strategies }\end{array}$ & \\
Proactive & Social Joint Venture & \\
& Strategy & Social Licensing Strategy \\
\cline { 2 - 3 } Cooperative & Social Franchise Strategy & Simultaneous \\
& Social Price- & Scaling-up \\
and \\
Competitive
\end{tabular}

(Source: Authors'own work)

While an SE strategy is going to be implemented at the macro-level, which must inevitably be formulated by government officials, fours variables must be taken into consideration:

(1) Degree of internationalism, i.e. how much the government intends to rely on international social organisations to implement its strategies.

(2) Degree of internalism, i.e. how much the government intends to rely on national organisations, resources and capabilities for the SE strategy implementation.

(3) Degree of governmentalism, i.e. how much the government intends to interfere and meddle with the SE implementation?

(4) Degree of volunteerism, i.e. how much the government lets the NGOs, SEOs and volunteers to do the job.

Answers to the above-mentioned questions would guide the governments to choose an appropriate strategic mix. The interplay of these four two by two contrary in nature variables, would logically in a conceptual 
framework, appear as direct opposites, i.e. logically they must have inverse or negative correlative relationship, thus four classes of state-promoted SE are possible (Figure 3).

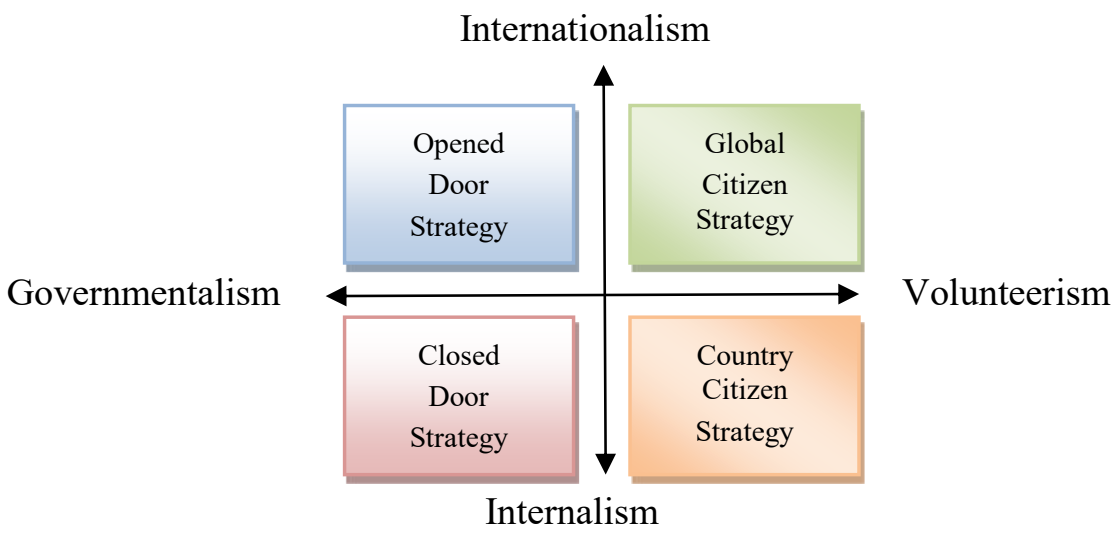

Figure 3: Classification of State-Sponsored SE Strategies

If a state pursues SE by close cooperation between the government and international organisations to answer social problems, it is a statesponsored SE strategy which could be called 'Opened Door Strategy'. Such a state tries to compensate its weak points and benefiting from international resources by some of the SE strategies, which are discussed previously, such as social licensing strategy, social franchising strategy and social joint venture strategy. In 'Opened Door Strategy' the social licensor, franchiser and partner is a foreign organisation, social entrepreneur or even a foreign government/state. Based on the proposed strategic mix in Table 4, the government pursing 'Opened Door Strategy' would choose a cooperative positioning in relation to the international and foreign partners.

The second class of state-sponsored strategies could be called 'Closed Door Strategy'. If a government completely or partially limits any volunteer activity by NGOs, national and international social entrepreneurs and organisations and on the other hand, tries to have a tight monopoly on any SE activities, it pursues a strategy based on governmentalist and internalist orientations. Such a state is not eager to accept any cooperation, or if it accepts, it is from a limited number of internal SE practitioners. The 
positioning of the government is mostly aggressive and in some cases, a defensive one since it does not trust national and international partners. Since the government looks at the international organisations as its rivals, it could sometime show competitive positioning too. States with 'Closed Door Strategy' potentially could apply social microfinance strategy and show socialism/communism propensities toward SE.

The third quadrant, which is the most optimal state strategy for the promotion of SE, is 'Global Citizen Strategy'. Government in this strategy functions as SE regulator and facilitator. It tries not to interfere overly in SE activities and trust the national and international SE organisations and social entrepreneurs. Moreover, it respects volunteering activities and accepts NGOs as its partners and contributors not its rivals. Based on' the proposed strategic mix in Table 4, these states would choose a cooperative positioning in dealing with active social entrepreneurs and in some cases proactive in dealing with future or emerging social problems. The proactive positioning of the government provides opportunities for scientific counselling with the SE experts and accepting their criticisms. Additionally, these states usually chooses one or several of scaling strategy, replication strategy, dissemination strategy and affiliation strategies to promote, scale up and replicate SE.

The last quadrant is 'Country Citizen Strategy'. The state accepts Volunteerism but within and from the internal social entrepreneurs and SEOs. The state's positioning toward SE promotion is defensive and in some cases by aggressive measures limit the activity of international social entrepreneurs. Moreover, such strategies inevitably relies heavily on the national resources for the promotion of SE. Social price-differentiation strategy, social cross-subsidisation strategy, social microfinance strategy and base-of-the-pyramid strategy could be classified within this quadrant with two conditions, first if the government only accepts volunteering from internal resources and second if it limits its interference with their activities as much as possible. 


\section{CONCLUSION}

The paper proposed and introduced a classification framework for statesponsored SE strategies based on four large-scale orientations in dealing with macro-level SE within states. These orientations consisted of internationalism versus internalism, and governmentalism versus volunteerism. Furthermore, a matrix for the possible combination of state-sponsored SE based on three issues of 'governmental strategic positioning toward SE', 'SE strategies' and 'intended results' for scaling and/or replication of SE or its social impact was proposed. The strategic mix contributes governments in setting customised and localised SE to be as effective and tailored to the communities need as possible. Additionally, the classification framework not only will facilitate the clarification and classification of governments' orientation toward SE, but also potentially would lead to a framework for teaching of state-promoted SE strategies in the academic context. Finally, the current paper present a conceptual framework for future researchers in the realm of strategic SE. Especially; it would be fruitful if an empirical research can be carried out to shed light on the nature and inverse correlation of the variables in the conceptual framework.

\section{REFERENCES}

Adams, D. (2009). A social inclusion strategy for Tasmania (Appendix 1). Department of Premier \& Cabinet (Social Inclusion Unit), Hobart.

Adetu, S. (2014) AIESEC Pursues Social Entrepreneurship for Economic Development. Retrieved on 26 September 2016, from http://www. spyghana.com/aiesec-pursues-social-entrepreneurship-economicdevelopment.

Ahlert, D., Ahlert, M., DuonDinh H.V., Fleisch, H., Heußler, T., Kilee, L., \& Meuter, J. (2008) Social Franchising: A Way of Systematic Replication to Increase Social Impact. Berlin: Bundesverb and Deutscher Stiftungen.

Alvord, S.H., Brown, L.D., and Letts, C.W. (2004). Social entrepreneurship and societal transformation: An exploratory study. Journal of Applied Behavioural Science, 40(3), 260-282. https://doi. org/10.1177/0021886304266847 
Anderson, B. B. \& Dees, J. G. (2002). Developing viable earned income strategies. In J. G. Dees, J. Emerson, and P. Economy (Eds.), Strategic Tools for Social Entrepreneurs: Enhancing the Performance of Your Enterprising Non-profit. New York: John Wiley and Sons.

Austin, J., Stevenson, H. \& Wei-Skillern, J. (2012). Social and commercial entrepreneurship: same, different, or both?. Revista de Administração, 47(3), 370-384. https://doi.org/10.5700/rausp1055

Auvinet, C. \& Lloret, A. (2015). Understanding social change through catalytic innovation: Empirical findings in Mexican social entrepreneurship. Canadian Journal of Administrative Sciences/Revue Canadienne des Sciences de l'Administration, 32(4), 238-251. https://doi.org/10.1002/ cjas. 1353

Bacq, S. \& Eddleston, K. A. (2018). A resource-based view of social entrepreneurship: how stewardship culture benefits scale of social impact. Journal of Business Ethics, 152(3), 589-611. https://doi. org/10.1007/s10551-016-3317-1

Bacq, S., Ofstein, L. F., Kickul, J. R. \& Gundry, L. K. (2015). Bricolage in social entrepreneurship: How creative resource mobilization fosters greater social impact. The International Journal of Entrepreneurship and Innovation, 16(4), 283-289. https://doi.org/10.5367/ijei.2015.0198

Battilana, J., Lee, M., Walker, J. \& Dorsey, C. (2012). In search of the hybrid ideal. Retrieved on 14 October 2017, from https://ssir.org/articles/entry/ in_search_of_the_hybrid_ideal\#

Berthon, P., McHulbert, J. \& Pitt, L. (2004). Innovation or customer orientation? An Empirical Investigation. European Journal of Marketing, 38(9/10), 1065-1090. https://doi.org/10.1108/03090560410548870

Bloom, P. \& Smith, B.R. (2010) Identifying the drivers of social entrepreneurial impact: Theoretical development and an exploratory empirical test of SCALERS. Journal of Social Entrepreneurship, $1(1), 126-145$. 
Bloom, P. N. \& Chatterji, A. K. (2009). Scaling social entrepreneurial impact. California Management Review, 51(3), 114-133. https://doi. org/10.2307/41166496

Brouard, F., Hebb, T. \& Madill, J. (2008). Development of a social enterprise typology in a Canadian context. Retrieved on 18 October 2017, from https://carleton.ca/3ci/wp-content/uploads/SETypologyPaper2.pdf .

Bugg-Levine, A., Kogut, B. \& Kulatilaka, N. (2012). Unbundling societal benefits and financial returns can dramatically increase investment. Harvard Business Review, 120-122.

Chalmers, D. (2013). Social innovation: an exploration of the barriers faced by innovating organisations in the social economy. Local Economy, 28(1), 17-34. https://doi.org/10.1177/0269094212463677

Chandra, Y., Jiang, L. C. \& Wang, C. J. (2016). Mining social entrepreneurship strategies using topic modeling. PloS one, 11(3), e0151342. https://doi. org/10.1371/journal.pone.0151342

Cheah, J., Amran, A. \& Yahya, S. (2019). Internal oriented resources and social enterprises' performance: How can social enterprises help themselves before helping others? Journal of Cleaner Production, 211, 607-619. https://doi.org/10.1016/j.jclepro.2018.11.203

Choi, D. \& Gray, E. (2008). The venture development processes of "sustainable" entrepreneurs. Management Research News, 8(31), 558-569. https://doi.org/10.1108/01409170810892127

Choi, N. \& Majumdar, S. (2014). Social entrepreneurship as an essentially contested concept: Opening a new avenue for systematic future research. Journal of Business Venturing, 29(3), 363-376. https://doi.org/10.1016/j. jbusvent.2013.05.001

Christiansen, C. (1997). The Innovators'Dilemma. Cambridge: Harvard Business School Press. 
Cohen, B. \& Winn, M. (2007). Market imperfections, opportunity and sustainable entrepreneurship. Journal of Business Venturing, 22(1), 29-49. https://doi.org/10.1016/j.jbusvent.2004.12.001

Dharani, K. (2014). The Biology of Thought: A Neuronal Mechanism in the Generation of Thought-A New Molecular Model. United Kingdom: Academic Press. https://doi.org/10.1016/C2013-0-19045-9

Davis, S. (2016). Relocating development communication: Social entrepreneurship, international networking, and South-South cooperation in the Viva Rio NGO. International Journal of Communication, 10, 18.

Dawson, P. \& Daniel, L. (2010). Understanding social innovation: a provisional framework. International Journal of Technology Management, 51(1), 9-21. https://doi.org/10.1504/IJTM.2010.033125

Dees, G.J., Emerson, J. \& Economy, P. (2002). Strategic Tools for Social Entrepreneurs: Enhancing the Performance of Your Enterprising NonProfit. New York: Wiley.

Dees, J.G. (2007). Taking social entrepreneurship seriously. Society, 44(3), 24-31. https://doi.org/10.1007/BF02819936

Dees, J.G. (2008) Developing the field of social entrepreneurship. Center for the advancement of social entrepreneurship. Duke University, Oxford

Dees, J.G. (1998a). Enterprising non-profits: What do you do when traditional sources of funding fall short? Harvard Business Review, January/February, 55-67.

Dees, J.G. (1998b). The meaning of social entrepreneurship, (2001 Revision). Retrieved on 14 October 2017, from https://entrepreneurship. duke.edu/news-item/the-meaning-of-social-entrepreneurship/

Dees, J.G., Anderson, B. B. \& Wei-Skillern, J. (2004). Scaling social impact. Stanford Social Innovation Review, 1(4), 24-32. 
Desa, G. (2012). Resource mobilization in international social entrepreneurship: Bricolage as a mechanism of institutional transformation. Entrepreneurship Theory and Practice, 36(4), 727-751. https://doi.org/10.1111/j.1540-6520.2010.00430.x

Drayton, W. (2002). The citizen sector: Becoming as entrepreneurial and competitive as business. California Management Review, 44(3), 120132.

El Ebrashi, R. (2013). Social entrepreneurship theory and sustainable social impact. Social Responsibility Journal, 9(2), 188-209. https://doi. org/10.1108/SRJ-07-2011-0013

Emerson, J., and Twersky, F. (1996). New Social Entrepreneurs: The Success, Challenge and Lessons of Non-Profit Enterprise Creation. San Francisco: The Roberts Foundation.

Ferreira, J. (2002). Corporate entrepreneurship: a strategic and structural perspective. New England Journal of Entrepreneurship, 4(2), 59-70. https://doi.org/10.1108/NEJE-04-02-2001-B006

Forouharfar, A. (2018). Social entrepreneurship strategies by the Middle Eastern governments: a review. In Faghih N., Zali M. (eds). Entrepreneurship Ecosystem in the Middle East and North Africa (MENA). Cham: Springer.

Forouharfar, A., Rowshan, S. A. \& Salarzehi, H. (2018). An epistemological critique of social entrepreneurship definitions. Journal of Global Entrepreneurship Research, 8(1), 1-40. https://doi.org/10.1186/s40497018-0098-2

Franz, H. W., Hochgerner, J. \& Howaldt, J. (Eds.). (2012). Challenge Social Innovation: Potentials for Business, Social Entrepreneurship, Welfare and Civil Society. Springer Science and Business Media.

Galera, G. \& Borzaga, C. (2009). Social enterprise: an international overview of its conceptual evolution and legal implementation. Social Enterprise Journal, 5(3), 210-228. https://doi.org/10.1108/17508610911004313 
Gandhi, T. \& Raina, R. (2018). Social entrepreneurship: The need, relevance, facets and constraints. Journal of Global Entrepreneurship Research, 8(1), 9. https://doi.org/10.1186/s40497-018-0094-6

Gilson, L. L. \& Goldberg, C. B. (2015). Editors' comment: so, what is a conceptual paper? Group and Organisation Management, 40(2) 127-130. DOI: 10.1177/1059601115576425

Goldsmith, S. (2010). The Power of Social Innovation: How Civic Entrepreneurs Ignite Community Networks for Good. United State: John Wiley and Sons.

González, M. F., Husted, B. W. \& Aigner, D. J. (2017). Opportunity discovery and creation in social entrepreneurship: an exploratory study in Mexico. Journal of Business Research, 81, 212-220. https://doi. org/10.1016/j.jbusres.2016.10.032

Gras, D. \& Lumpkin, G. T. (2012). Strategic foci in social and commercial entrepreneurship: A comparative analysis. Journal of Social Entrepreneurship, 3(1), 6-23. https://doi.org/10.1080/19420676.201 2.660888

Greblikaite, J., Sroka, W. \& Grants, J. (2015). Development of social entrepreneurship in European Union: policy and situation of Lithuania and Poland. Transformations in Business and Economics, 14(2), 376396.

Grieco, C. (2015). Assessing Social Impact of Social Enterprises. Switzerland: Springer International Publishing. DOI: https://doi. org/10.1007/978-3-319-15314-8_2

Guclu, A., Dees, J.G. \& Anderson, B.B. (2002). The process of social entrepreneurship: Creating opportunities worthy of serious pursuit. Center for the Advancement of Social Entrepreneurship, 1, 1-15.

Haigh, N. \& Hoffman, A. (2012). Hybrid organisations: The next chapter of sustainable business. Organisational Dynamics, 41, 126-134. doi:10.1016/j.orgdyn.2012.01.006 
Hand, M. (2016). The Research Gap in Social Entrepreneurship. Stanford Social Innovation Review, May 24, Retrieved on 28 February 2019, from https://ssir.org/articles/entry/the_research_gap_in_social_ entrepreneurship

Hervieux, C., Gedajlovic, E. \& Turcotte, M.F.B. (2010). The legitimization of social entrepreneurship. Journal of Enterprising Communities: People and Places in the Global Economy, 4(1), 37-67. https://doi. org/10.1108/17506201011029500

Hibbert, S. A., and Hogg, G., Quinn, T. (2002). Consumer response to social entrepreneurship: The case of the big issue in Scotland. International Journal of Non-Profit and Voluntary Sector Marketing, 7(3), 288-301. https://doi.org/10.1002/nvsm.186

Hoffman, A.J., Badiane, K.K., and Haigh, N. (2010). Hybrid organisations as agents of positive social change: Bridging the for-profit and nonprofit divide, Ross School of Business, Working Paper. Retrieved on 14 October 2017, from http://ssrn.com/abstract=1675069.

Huda, M., Qodriah, S.L., Rismayadi, B., Hananto, A., Kardiyati, E.N., Ruskam, A., and Nasir, B.M. (2019). Towards cooperative with competitive alliance: Insights into performance value in social entrepreneurship. In Creating Business Value and Competitive Advantage with Social Entrepreneurship. USA: IGI Global. DOI: 10.4018/978-1-5225-5687-9.ch014

Ireland, R. D., Covin, J. G., and Kuratko, D. F. (2009). Conceptualizing corporate entrepreneurship strategy. Entrepreneurship Theory and Practice, 33(1), 19-46. https://doi.org/10.1111/j.15406520.2008.00279.x

Jiao, H. (2011). A conceptual model for social entrepreneurship directed toward social impact on society. Social Enterprise Journal, 7(2), 130149. https://doi.org/10.1108/17508611111156600

Kerlin, J. A. (2006). Social enterprise in the United States and Europe: understanding and learning from the differences. Voluntas: International 
Journal of Voluntary and Nonprofit Organisations, 17(3), 246. https:// doi.org/10.1007/s11266-006-9016-2

Kerlin, J. A. (2010). A comparative analysis of the global emergence of social enterprise. Voluntas: International Journal of Voluntary and Nonprofit Organisations, 21(2), 162-179. https://doi.org/10.1007/ s11266-010-9126-8

Kuratko, D.F. \& Audretsch, D.B. (2017). Strategic entrepreneurship: exploring different perspectives of an emerging concept. Entrepreneurship Theory and Practice, 33(1), 1-17. https://doi.org/10.1111/j.15406520.2008.00278.x

Kuratko, D.F. \& Hodgetts, R.M.(1995). Entrepreneurship: A Contemporary Approach, $3^{\text {rd }}$ Ed. Orlando: Dryden Press.

Lasprogata, G.A. \& Cotton, M.N. (2003). Contemplating enterprise: the business and legal challenges of social entrepreneurship. American Business Law Journal, 41(1), 67.

Lisetchi, M. \& Brancu, L. (2014). The entrepreneurship concept as a subject of social innovation. Procedia-Social and Behavioural Sciences, 124, 87-92. https://doi.org/10.1016/j.sbspro.2014.02.463

London, T. \& Hart, S.L. (2011) Next Generation Business Strategies for the Base of the Pyramid: New Approaches for Building Mutual Value. Upper Saddle River: Pearson Education.

Longman Advanced American Dictionary (2007). “Replication”, 1341.

Luke, B., Kearins, K. \& Verreynne, M.L. (2011). Developing a conceptual framework of strategic entrepreneurship. International Journal of Entrepreneurial Behavior and Research, 17(3), 314-337. https://doi. org/10.1108/13552551111130736

Maclean, M., Harvey, C. \& Gordon, J. (2013). Social innovation, social entrepreneurship and the practice of contemporary entrepreneurial philanthropy. International Small Business Journal, 31(7), 747-763. https://doi.org/10.1177/0266242612443376 
Mair, J. \& Marti, I. (2006). Social entrepreneurship research: a source of explanation, prediction, and delight. Journal of World Business, 41(1), 36-44. https://doi.org/10.1016/j.jwb.2005.09.002

Manton, S. (2005). Integrated Intellectual Asset Management. United Kingdom: Gower Publishing Ltd.

Marshall, R.S. (2011). Conceptualizing the international for-profit social entrepreneur. Journal of Business Ethics, 98(2), 183-198. https://doi. org/10.1007/s10551-010-0545-7

Mort, G., Weerawardena, J. \& Carnegie, K. (2002). Social entrepreneurship: towards conceptualisation. International Journal of Non-profit and Voluntary Sector Marketing, 8(1), 76-88. DOI: 10.1002/nvsm.202

Mulgan, G. (2006). The process of social innovation. Innovations: Technology, Governance, Globalization, 1(2), 145-162. https://doi. org/10.1162/itgg.2006.1.2.145

Munoz, J. M. (2010). International Social Entrepreneurship: Pathways to Personal and Corporate Impact. New York: Business Expert Press.

Nicholls, A. (2009). 'We do good things, don't we?': 'Blended value accounting' in social entrepreneurship. Accounting, Organisations and Society, 34(6-7), 755-769. https://doi.org/10.1016/j.aos.2009.04.008

Nicholls, A. (Ed.). (2008). Social Entrepreneurship: New Models of Sustainable Social Change. Oxford: Oxford University Press.

Nicholls, A. \& Cho, A. (2006). Social entrepreneurship: The structuration of a field. In A. Nicholls (Ed.), Social Entrepreneurship: New Models of Sustainable Social Change. Oxford: Oxford University Press.

Nicholls, A. \& Murdock, A. (2012). The nature of social innovation. In Nicholls, A. \& Murdock, A.(Eds) Social Innovation. London: Palgrave Macmillan.

Nicholls, A. \& Murdock, A. (Eds.). (2011). Social Innovation: Blurring Boundaries to Reconfigure Markets. London: Palgrave Macmillan. 
Ormiston, J. \& Seymour, R. (2011). Understanding value creation in social entrepreneurship: The importance of aligning mission, strategy and impact measurement. Journal of Social Entrepreneurship, 2(2), 125150. https://doi.org/10.1080/19420676.2011.606331

Peredo, A. M. \& McLean, M. (2006). Social entrepreneurship: A critical review of the concept. Journal of World Business, 41(1), 56-65.

Perrini, F., Vurro, C. \& Costanzo, L. A. (2010). A process-based view of social entrepreneurship: from opportunity identification to scaling-up social change in the case of San Patrignano. Entrepreneurship and Regional Development, 22(6), 515-534. https://doi.org/10.1080/0898 5626.2010 .488402

Phillips, W., Lee, H., Ghobadian, A., O'Regan, N. \& James, P. (2015). Social innovation and social entrepreneurship: A systematic review. Group and Organisation Management, 40(3), 428-461. https://doi. org/10.1177/1059601114560063

Picot, S. (2012). Jugend in der Zivilgesellschaft - Freiwilliges Engagement Jugendlicher im Wandel (Young people in civil society - Voluntary engagement in the process of change). Gütersloh: Verlag Bertelsmann Stiftung.

Prabhu, G. N. (1999). Social entrepreneurship leadership. Career Development International, 4(3), 140-145. https://doi. org/10.1108/13620439910262796

Rawhouser, H., Cummings, M. \& Newbert, S.L. (2019). Social impact measurement: current approaches and future directions for social entrepreneurship research. Entrepreneurship Theory and Practice, 43(1), 82-115. https://doi.org/10.1177/1042258717727718

Rowshan, A. \& Forouharfar, A. (2014). Customised social entrepreneurship theory and customised social entrepreneurship strategy as a theory conceptualisation and practice towards sustainable development in Iran. Asian Journal of Research in Social Sciences and Humanities, 4(8), 367-385. 
Rwigema, H. \& Venter, R. (2004). Advanced Entrepreneurship. Cape Town: Oxford University Press.

Sarasvathy, S.D. \& Wicks, A.C. (2003). Value Creation through entrepreneurship: Reconciling the two meanings of the good life. Under revision by Academy of Management Review.

Scheuerle, T., Schües, R. \& Richter, S. (2013). Mapping social entrepreneurship in Germany: A quantitative analysis. Centre for Social Investment, University of Heidelberg.

Sekliuckiene, J. \& Kisielius, E. (2015). Development of social entrepreneurship initiatives: A theoretical framework. Procedia-Social and Behavioural Sciences, 213, 1015-1019. https://doi.org/10.1016/j. sbspro.2015.11.519

Shockley, G.E. \& Frank, P.M. (2011). The functions of government in social entrepreneurship: theory and preliminary evidence. Regional Science Policy and Practice, 3(3), 181-198. https://doi.org/10.1111/j.17577802.2011.01036.x

Stryjan, Y. (2006). The practice of social entrepreneurship: Notes toward a resource perspective. In C. Steyaert and D. Hjorth (Eds.), Entrepreneurship as Social Change: A Third Movements in Entrepreneurship Book. Cheltenham: Edward Elgar Publishing.

Tapsell, P. \& Woods, C. (2008). A spiral of innovation framework for social entrepreneurship: Social innovation at the generational divide in an indigenous context. Emergence: Complexity and Organisation, 10(3), 25. Doi: 10.emerg/10.17357.797d98a5e5aa6cf71edc310b4b2aff01.

Tapsell, P. \& Woods, C. (2010). Social entrepreneurship and innovation: self-organisation in an indigenous context. Entrepreneurship and Regional Development, 22(6), 535-556. https://doi.org/10.1080/0898 5626.2010 .488403

Thake, S. \& Zadek S. (1997). Practical People, Noble Causes: How to Support Community-Based Social Entrepreneurs. London: New Economics Foundation. 
Thompson, J., Alvy, G. \& Lees, A. (2000). Social entrepreneurship-a new look at the people and the potential. Management Decision, 38(5), 328338. https://doi.org/10.1108/00251740010340517

Timmons, J.A. \& Spinelli, S. (2003). New Venture Creation: Entrepreneurship for the $21^{\text {st }}$ Century. Boston: McGraw- Hill.

Townsend, D.M. \& Hart, T.A. (2008). Perceived institutional ambiguity and the choice of organisational form in social entrepreneurial ventures. Baylor University. Retrieved on 14 October 2017, from http://ssrn.com/ abstract $=1313848$.

Tracey, P. \& Jarvis, O. (2007). Toward a theory of social venture franchising. Entrepreneurship Theory and Practice, 31(5), 667-685. https://doi. org/10.1111/j.1540-6520.2007.00194.x

Van der Have, R.P. \& Rubalcaba, L. (2016). Social innovation research: An emerging area of innovation studies? Research Policy, 45(9), 19231935. https://doi.org/10.1016/j.respol.2016.06.010

Volkmann, C.K., Tokarski, K.O. \& Ernst, K. (2012). Background, characteristics and context of social entrepreneurship. In Volkmann C., Tokarski K. \& Ernst K. (Eds.) Social Entrepreneurship and Social Business. Germany: Springer, Gabler. DOI: https://doi.org/10.1007/9783-8349-7093-0

Volkmann, C.K., Goia, S.I. \& Hadad, S. (2018). Social entrepreneurship across the European Union: an introduction. In Dima A. (Eds.) Doing Business in Europe. Cham: Springer.

Waddock, S. \& Post, J.E. (1991). Social entrepreneurs and catalytic change. Public Administration Review, 51(5), 393-401. DOI: 10.2307/976408

Weerawardena, J. \& Mort, G.S. (2006). Investigating social entrepreneurship: A multidimensional model. Journal of World Business, 41(1), 21-35. https://doi.org/10.1016/j.jwb.2005.09.001 
Weisbrod, B.A. (1977). Book review: The voluntary nonprofit sector. Journal of Political Economy, 87(3), 669-672.

Westley, F. \& Antadze, N. (2010). Making a difference: strategies for scaling social innovation for greater impact. Innovation Journal, 15(2), Article 2.

Whetten, D. (1989). What constitutes a theoretical contribution? Academy of Management Review, 14(4), 490-495. https://doi.org/10.5465/ amr.1989.4308371

Zahra, S.A., Newey, L.R. \& Li, Y. (2014). On the frontiers: the implications of social entrepreneurship for international entrepreneurship. Entrepreneurship Theory and Practice, 38(1), 137-158. http://dx.doi. org/10.2139/ssrn.2286150

Zahra, S.A., Rawhouser, H.N., Bhawe, N., Neubaum, D.O. \& Hayton, J.C. (2008). Globalization of social entrepreneurship opportunities. Strategic Entrepreneurship Journal, 2(2), 117-131. DOI: 10.1002/sej.43

Zald, M. (2000). Ideologically structured action: an enlarged agenda for social movement research. Mobilization: An International Quarterly, 5(1), 1-16.

Zald, M. \& Davis, G. (2005). Social change, social theory, and the convergence of movements and organisations. In Davis, G., McAdam, D., Scott. W., Zald, M. (Eds.) Social Movements and Organisation Theory. Cambridge: Cambridge University Press.

Zander, I. \& Zander, U. (2005). The inside track: On the important (but neglected) role of customers in the resource-based view of strategy and firm growth. Journal of Management Studies, 42(8), 1519-1548. https://doi.org/10.1111/j.1467-6486.2005.00555.x

Zietlow, J.T. (2002). Releasing a new wave of social entrepreneurship. Non-profit Management and Leadership, 13(1), 85-90. https://doi. org/10.1002/nml.13107 
Introducing A Conceptual Framework for the Strategic Classification of State-Sponsored Social

Żur, A. (2015). Social problems as sources of opportunity: antecedents of social entrepreneurship opportunities. Entrepreneurial Business and Economics Review, 3(4), 73-87. https://doi.org/10.15678/ EBER.2015.030405 